Article

\title{
The International Labour Standards Debate in the Brazilian Labour Movement: Engagement with Mercosur and Opposition to the Free Trade Area of the Americas
}

\author{
Marieke Riethof \\ Modern Languages \& Cultures/Latin American Studies, University of Liverpool, Liverpool, L69 7ZR, UK; \\ E-Mail: mriethof@liverpool.ac.uk.
}

Submitted: 3 July 2017 | Accepted: 3 November 2017 | Published: 14 December 2017

\begin{abstract}
The social dimensions of economic integration have become an increasingly significant feature of trade agreements, particularly those between developing countries. In the Brazilian case trade-related labour standards have not become a major feature outside of the regional organization Mercosur (Common Market of the South), yet we know relatively little about the reasons for this discrepancy. Paradoxically one of the main stakeholders in this debate, Brazilian trade unions, has broadly supported social and labour clauses in the regional context but union activists have opposed labour provisions in trade negotiations between asymmetric partners. A comparative analysis of the labour campaigns in Mercosur and the Free Trade Area of the Americas (FTAA) negotiations explains this ambiguity in terms of Brazilian labour strategies towards free trade negotiations and explores their implications for evaluations of labour attitudes to trade-related labour standards in developing countries. The labour movement's own conflicting perspectives on the trade-labour connection are a key explanation of these outcomes, reinforcing the need for a greater appreciation of the complexity of trade union views in the debate on labour standards.
\end{abstract}

\section{Keywords}

Brazil; Free Trade Area of the Americas; FTAA; globalization; international labour standards; labour unions; Latin America; Mercosur; regional integration; trade

\section{Issue}

This article is part of the issue "Labour Standards in a Global Environment", edited by Gerda Van Roozendaal (University of Groningen, The Netherlands) and Jan Orbie (Ghent University, Belgium).

(C) 2017 by the author; licensee Cogitatio (Lisbon, Portugal). This article is licensed under a Creative Commons Attribution 4.0 International License (CC BY).

\section{Introduction}

Brazilian trade unions have viewed free trade agreements and trade-related labour standards with considerable suspicion based on what they perceive as the predominantly negative effects of free trade on jobs and working conditions. Their objections refer both to the perceived negative impact of trade liberalization on developing countries such as Brazil as well as suspicions about making free trade conditional on compliance with international labour standards. These criticisms do not imply that Brazilian unionists object to international labour standards; on the contrary, they have actively incorporated the international labour standards agenda in domestic campaigns since the late 1970s. However, their argument is that labour clauses in trade agreements can amount to veiled protectionism if they involve economic sanctions in the case of labour rights violations. In the eyes of many trade unionists in developing countries, such efforts can lead to job losses instead of an improvement of workers' rights. Despite these criticisms, unionists have in fact engaged with the debate about trade and labour standards in the context of free trade negotiations and regional integration since the early 1990s. Faced with the reality of trade agreements, unionists have participated in these negotiations so as to have a voice in what they have come to view as an inevitable process. Yet the dilemma of whether to participate in the 
debate and the institutions associated with trade agreements, or to mobilize against them, is evident in their strategies and stance towards the negotiation process and its aftermath.

To explain how this dilemma affects labour strategies towards free trade agreements in developing countries, the article examines two case studies of labour engagement in trade negotiations in the Americas, namely Mercosur (Common Market of the South) ${ }^{1}$ and the FTAA (Free Trade Area of the Americas). In the case of Mercosur, the Brazilian labour movement actively participated in institutional structures focused on the labour and social dimensions of the integration process since the early 1990s. In the case of the FTAA, Brazilian unions rejected the agreement, including the prospect of labour and environmental clauses. A comparative analysis of trade union strategies concerning two of Brazil's most important trade agreements between 1990 and 2005 explains why the trade union perspective on free trade has varied so significantly between Mercosur and the FTAA, which has subsequently also shaped the actual impact of labour standards in trade agreements in Brazil. In the case of Mercosur, while labour standards are part of the organization's institutional framework, they are neither binding-as trade unions had initially proposed-nor linked to trade. Nevertheless, Mercosur has facilitated regional collaboration among trade unionists, whose lobbying resulted in a declaration on social and labour rights. Although the FTAA never materialized the negotiations unified and solidified labour and civil society opposition to free trade, including trade-related labour standards, which continues to resonate in the region today.

The central argument is that the extent to which labour standards were included in these trade negotiations cannot be understood without reference to the complexity of trade union perspectives on trade-related labour standards. Although the social and labour outcomes of free trade agreements depend on a wide variety of factors, including government and business attitudes as well as the dynamics of regional trade negotiations in different parts of the world, trade union voices in developing countries should be considered a significant part of the story. These perspectives have also shaped how trade unionists dealt with the dilemma of engagement with, or opposition to, trade agreements, which have played out in different ways during the Mercosur and FTAA negotiations, underlining the significance of domestic agency in shaping the outcomes of the debate on the trade-labour linkage. The article shows that labour opposition to trade-related labour standards is not necessarily the norm in a developing country like Brazil since union strategies are shaped instead by perceptions of how engagement with free trade negotiations might harm or benefit the promotion of workers' interests. The comparative case studies also show that even though the outcomes of trade negotiations involving Brazil have remained limited in terms of labour clauses, the participatory structures in the case of Mercosur and civil society opposition to the FTAA created spaces for regional trade union collaboration. Despite the fact that the FTAA was never implemented, the negotiation process nevertheless had an impact on civil society debates on the social dimensions of free trade, solidifying the opposition to North-South trade agreements in much of Latin America. These outcomes reflect both the geopolitical characteristics of Mercosur and the FTAA, and the profound scepticism about trade-related labour standards commonly found in South America among trade union actors. Before examining Brazilian labour engagement with trade agreements in further detail, the article discusses how we can understand union perspectives on trade-related labour standards, emphasizing that these views are more complex than often suggested in the literature. Subsequently, it is necessary to turn to the Brazilian context to explain how ideas about the impact of globalization, free trade and development have informed Brazilian trade union strategies towards free trade agreements, followed by a comparison of labour campaigns in the cases of Mercosur and the FTAA.

\section{Understanding Labour Movement Perspectives on Free Trade and Labour Standards.}

Provisions to promote labour standards can be found in all South-South trade agreements, including in regional organizations in the Americas (International Labour Organization [ILO], 2015, p. 67). The underlying assumption of connecting trade to working conditions is that market access can be made conditional upon developing countries' compliance with the international labour standards agenda. Due to their "soft law" nature-the lack of regulation and sanctions attached to labour rights violations-international labour standards are notoriously hard to enforce (Pahle, 2014a, pp. 130-131), so the rationale for trade-related labour standards is that countries have to introduce labour reforms and continue to monitor progress to qualify for a trade agreement (ILO, 2015, p. 30). A more common practice is to incorporate positive incentives to respect labour rights, including mechanisms to improve working conditions by fostering cooperation between unions, monitoring of labour conditions, and in some cases complaint mechanisms (ILO, 2015, pp. 70-71). However, despite their growing importance in bilateral and multilateral trade agreements trade-related labour standards have had a limited impact in Brazil. In the most important trade negotiations for Brazil since the early 1990s, labour provisions either did not materialize or have been relatively limited. In the case of Mercosur, debates about the social dimensions of regional integration resulted in a declaration on labour rights and formal civil society consultation, while in the case of the FTAA, the proposed labour and environmen-

\footnotetext{
${ }^{1}$ Because the Spanish acronym for the Mercado Común del Sur is more widely used than the Portuguese Mercosul, I will use Mercosur throughout the article.
} 
tal clauses were abandoned amidst widespread opposition to free trade. The outcomes of both cases should of course not be reduced to labour campaigns (Arashiro, 2011; Phillips, 2004) but an analysis of the trade union perspective illustrates the complex nature of the tradelabour debate in a Latin American context. In particular, trade union perceptions of the geopolitical differences between both trade agreements shaped the unions' ambiguous approach to labour standards, despite the existence of limited participatory structures for labour and civil society actors in both cases. To understand the reasons for these differing outcomes it is necessary to explore the debate about the advantages and disadvantages of labour provisions from the perspective of the labour movement.

A significant part of the explanation for the ambiguity in Brazilian trade union support for labour clauses can be found in ideas among Brazilian union activists about globalization, free trade and social conditions and how these have informed their strategies to influence trade negotiations. Analyses of trade-labour debate in developing countries are often based on the assumption that workers in countries such as Brazil oppose labour standards in trade agreements primarily due to wariness of unfair competition and protectionism (Bieler, Hilary, \& Lindberg, 2014, p. 6; González Garibay, 2009). The idea that labour standards can be protectionist is based on the view that developing countries have a comparative advantage in lower labour costs and levels of regulation than developed countries. From this perspective, if developing countries are forced to match international labour standards workers can face negative outcomes if companies cut jobs or move to another part of the world in search of lower labour costs. However, given the different outcomes of the Mercosur and FTAA negotiations in terms of the trade-labour linkage, this assumption only tells us part of the story and fails to explain why trade unions approached both cases differently. As Griffin, Nyland and O'Rourke (2002, pp. 4-7) argue, to understand these differences we need to take into account that trade unionists in the developing world have not always rejected the trade-labour linkage, reflecting a more complex set of considerations than often assumed. This assumption also reflects a failure to take into account how developing countries such as Brazil-and particularly civil society and labour actors (Nadvi, 2014, p. 143)engage with trade-related labour standards. Moreover, their position reflects what Orbie, Martens, Oehri and Van den Putte (2016, p. 527) call the "insider-outsider dilemma" of civil society engagement with free trade negotiations. Their study shows that in the case of the EU civil society actors have chosen to take part in participatory mechanisms so as not to lose a voice in the process, while also being aware that their participation may help legitimize free trade. The diversity of views about trade and labour among unionists therefore suggests the need to bring trade union views on, and strategies towards, trade agreements into the analysis.
To achieve a more nuanced understanding of the relationship between trade and labour standards in developing countries requires taking into account the interaction between labour politics, national political conjuncture, and the nature of the trade negotiations themselves. As recognized in the literature on the social dimensions of trade agreements, the effectiveness of trade-related labour standards depends on domestic political and legal contexts (ILO, 2015, p. 5). Similarly, the extent to which intensified trade deteriorates social and environmental conditions, and whether these effects can be mitigated is closely associated with the domestic regulatory context. To underline the importance of the domestic context in the case of Brazil, violations of fundamental labour rights have been particularly common in growing sectors of the economy, such as construction, export agriculture, infrastructure and natural resources. These violations have included forced labour, human trafficking, informality, poor working conditions as well as violations of the right to unionization and collective bargaining (International Trade Union Confederation, 2009). Not all of these cases have involved export-oriented sectors, which means that these violations reflect structural problems in Brazilian society, including high levels of informal labour associated with a lack of protection of workers' rights. In assessing the effectiveness of labour rights protection, Pahle (2014b) also emphasizes the importance of the domestic context, especially the structural and political conditions in which unions operate, including the relationship between labour's national and international agendas (Dobrusin, 2015, p. 280). Reflecting the growing attention to the role of political ideas in analyses of regional free trade debates (Arashiro, 2011; Nelson, 2015; Phillips, 2004), another layer of my analysis of the ambiguities in labour strategies therefore refers to the Brazilian union movement's own conflicting views on international labour standards, globalization and free trade.

\section{Labour Movement Debates on the Trade-Labour Linkage: Global and Regional Dimensions}

Brazilian trade unionists' perceptions of free trade reveal a paradox in how they understand the relevance of trade-related labour standards, which has informed labour strategies both in the case of Mercosur and the FTAA. As expressed in numerous union documents and in interviews I have conducted, Brazilian unionists have focused their diagnosis of labour market problems on the structural inequalities associated with the way capitalism operates in Brazil, a dynamic compounded by the country's asymmetrical relationship with the global economy. In their view, due to the unequal position of Brazilian workers within their own country and the globalized economy, the expansion of free trade could only lead to the deepening of these inequalities and the weakening of unions, meaning that trade agreements should be rejected altogether. From the union movement's perspective, trade-related labour standards could not address 
these structural inequalities because they have viewed free trade as perpetuating developing countries' unequal position in the world economy. In turn, Brazilian unions' views on labour rights, globalization, development and trade have shaped their perceptions of how trade and labour provisions affect working conditions in developing countries. Thus, in their view Mercosur and the FTAA reflected different manifestations of globalization and free trade, with a differential impact on workers. The following discussion is based on an analysis of the debates within Brazil's largest national trade union organization, the Central Única dos Trabalhadores (Unified Workers' Centralor CUT). In 2016, the CUT's membership represented 3.8 million, or approximately one-third of Brazil's unionized workers across the industrial, public and rural sectors (Confederação Nacional de Profissionais Liberais, 2016).

Even before Brazil's trade balance tipped towards exports of natural resources and agricultural products in the early 2000s, unionists reached for the classic dependency explanation that expanding agricultural and mineral exports would make the Brazilian economy especially vulnerable to the volatility of international markets (CUT, 1994, p. 7). Not only would an export-focused development strategy promote products with low added value (such as agricultural goods), thereby creating poor working conditions rather than high-quality and wellpaid jobs, the opening up of Brazil's markets would have immediate and negative consequences for workers due to global competition, leading to reduced wages and the erosion of labour rights (CUT, 1997, p. 7). From this perspective, the expansion of free trade as part of the globalization process would inevitably deepen social exclusion. According to the CUT's former president, Vicente Paulo da Silva (1994-1996), "workers from all over the world are under pressure to abandon their rights and legitimate demands in the name of international competition. At the same time, unemployment increases, and we see an enormous concentration of power and wealth" (Silva, n.d.). ${ }^{2}$ In the CUT's analysis of globalization's impact on Brazil during the 1990s, multinational corporations and international financial institutions were the driving forces behind economic integration, underlining the point that trade was only part of the story, while their experience with multinationals showed that company strategies were focused on driving down wages and working conditions in their search for profits. This interpretation of globalization and its impact on Brazilian workers meant that union representatives have generally believed that trade agreements would deepen the country's social problems, which could not be remedied by a given social clause.

These considerations do not imply that the CUT has opposed all regional and global trade agreements, as they have recognized the potential for civil society to contribute to sustainable global and regional economic integration (Castro, 1999, p. 12). This distinction became particularly apparent in civil society attitudes to Merco- sur in the 1990s and the FTAA from the late 1990s to the mid-2000s. While unionists viewed Mercosur as an organization with the potential to withstand the pressures of globalization, they saw the FTAA as dictated by the US in an attempt to expand its economic interests in the Americas, with Latin American workers exclusively bearing the negative consequences. Based on the labour movement's evaluation of free trade and Mexico's experiences with the North-American Free Trade Agreement (NAFTA), union activists in the industrial sector expected regional integration between asymmetrical partners to lead to the downward harmonization of social and labour rights (author's interviews with Maria S. Portela de Castro, adviser Confederação Nacional dos Metalúrgicos, October and December 1999; Castro, 1999, p. 13). Their knowledge of Mexican and trade union experiences with NAFTA also underlined for Brazilian unionists and their Latin American counterparts their lack of a voice in what they saw as FTAA's singular focus on trade liberalization and economic deregulation. In the case of Mercosur, unions ended up participating in the formal institutions of the regional organization, while in the case of the FTAA there was a successful campaign to derail hemispheric trade negotiations. What these differences tell us about Brazilian union attitudes to trade-related labour standards is that their perceptions of the geopolitical nature of the respective negotiations-one between developing countries and the other dominated by the USwere a key factor in the unions' willingness to engage with labour provisions.

\subsection{Mercosur: Regional Integration as a Platform for Labour Campaigns}

As the main regional platform for debates on the social and labour dimensions of regional integration in Latin America, Mercosur became a significant focus for transnational union action in the 1990s. Mercosur also represents the clearest example in South America of a regional trade agreement's impact on domestic labour standards, particularly the creation of spaces for increased dialogue, cooperation and formal participation in Mercosur-supported institutions involving union and other civil society actors in the member states. This begs the question why labour actors decided to use Mercosur's negotiation process and formal institutions as an opportunity to draw attention to the social dimensions of economic integration, despite the Brazilian unionists' pessimistic views of trade agreements. To answer this, it is necessary to analyse how trade unionists viewed Mercosur in the context of the worsening recession of the 1990s, the impact of Mercosur's labour provisions and the creation of spaces for transnational union action associated with the Mercosur process.

Mercosur emerged at a time when Brazil was experiencing hyperinflation rates reaching four digits in 1993. Successive governments introduced neoliberal reforms

\footnotetext{
${ }^{2}$ All translations from Portuguese are by the author.
} 
such as privatization, budget cuts and trade liberalization to stabilize the economy. Part of this strategy to liberalize the economy was to create a regional common market on a regional scale before exposing Brazil to global competition (Phillips, 2004, p. 85). The labour movement experienced significant challenges during this period as the crisis led to job losses and unions increasingly struggled to develop an effective response (Riethof, in press, Chapter 4). Based on their experience of how labour issues were dealt with in NAFTA Brazilian unionists understood that a trade agreement between asymmetric partners could be detrimental to Latin American workers. They also understood the rationale for a Latin American trading bloc, which would allow governments to liberalize the economy in stages and to counter protectionism in developed countries by increasing trade with neighbouring countries (CUT, 2003, pp. 39-40). As Kjeld Jakobsen, CUT director of international relations between 1994 and 2003, explained:

The CUT's priority vis-à-vis Mercosur is to ensure that it does not just turn into a trade agreement that only benefits large corporations, but that it becomes an agreement for "mutual integration". In other words, if Brazil sells something to Argentina that we have and they don't, and vice versa, we can increase production, create more jobs. (as cited in Barbiero \& Chaloult, 2000, p. 65)

Thus despite their misgivings about the benefits of free trade for workers in developing countries, union activists viewed a Latin American trading bloc as having the potential to mediate the negative effects of globalization (CUT, 2003, p. 66; Phillips, 2004, p. 170), particularly if civil society activists managed to put pressure on their country's political leadership to create the necessary political will to do so. In effect, for unionists the geopolitical nature of Mercosur as a South-South agreement meant that fears that labour standards would lead to protectionism were less acute. ${ }^{3}$

Trade unionists also saw potential in Mercosur facilitating civil society participation in economic policy, in contrast to the government-dominated economic liberalization policies which were common in the 1990s. Mercosur created spaces for cross-border labour action as a regional "labour politics...emerged parallel to these regionalist negotiations and in important respects has acted to offset the ongoing marginalisation of labour" (Phillips, 2004 , p. 170). Regional union activism focused on coordinating the union position vis-à-vis Mercosur's agenda and strengthening its social dimensions. Consequently, a major focus of union activism was to lobby for the democratic participation of civil society in the regional integration process (CUT, 1994, p. 6). The main union organiza- tion involved in this process was the Coordinadora de Centrales Sindicales del Cono Sur (Co-ordination of Union Centrals in the Cono Sur, or CCSCS), founded in 1986 (Castro, 2007; CUT, 2003, p. 17). Several institutional structures dealing with social issues were the result of union lobbying (Dabène, 2009, p. 164; Godio, 2004, pp. 101-102), which included a working group and consultative forum focused on labour issues, a declaration of labour and social rights, and a regional commission to monitor the state of labour rights in Mercosur member states.

Although Mercosur's Treaty of Asunción (1991) focused primarily on economic and trade issues, it also established a tripartite working group dealing with labour and employment issues (SGT11, later SGT10) in 1991 and the Socio-Economic Consultative Forum (FCES) in 1994 (Castro, 1999, pp. 46-49). Within these structures, union strategies emphasized the inclusion of the ILO core labour standards in the regional integration process. As a CUT document explained, "the international labour norms as defined by the ILO were an important...incentive for the creation and improvement of jobs and to foster an equilibrium in trade relations" (CUT, 2003 , p. 63). Based on this view, unions lobbied for the adoption of a Mercosur Social Charter modelled on the EU's equivalent. The proposal specified a binding set of individual and collective labour rights, such as freedom of association, the right to strike and collective bargaining. The unions also proposed a tripartite body in charge of monitoring compliance with regional labour norms, including sanctions (CUT, 2003, pp. 68-69). Although such a far-reaching charter failed to materialize, mainly due to the proposed economic sanctions, Mercosur officially adopted the Declaration of Social and Labour Rights in 1998 and established the Social-Labour Commission to oversee social and labour rights in 1999. The Declaration was updated in 2015 to include a stronger focus on employment creation in times of crisis and the ILO's "decent work" agenda, following years of discussions among labour, business and government participants (CUT, 2015). As such, the Declaration moved beyond fundamental labour rights to include freedom of movement, social security and employment policy (Schaeffer, 2007, pp. 837-838). These examples show that despite the relatively limited scope of labour provisions in Mercosur, these outcomes are evidence of effective union engagement with Mercosur's participatory structures.

Unionists involved in the Mercosur process generally considered the Declaration a step forward for labour rights, despite the lack of sanctions. Reflecting the limitations of the original proposal, the CUT's Ericson Crivelli argued:

We worked with the notion of sanctions, which would mean the possibility of penalizing those who did not

\footnotetext{
${ }^{3}$ Due to the size of its economy, its foreign policy ambitions and regional investments Brazil has dominated Mercosur since its inception, which means that the relationship between the Mercosur member states is unequal. Zibechi $(2014$, loc. 132$)$ argues that under the Workers' Party governments (2003-2016) trade unions such as the CUT, as close government allies, effectively became complicit in the Brazilian government's strategy for regional dominance. In the political context of the 1990s, though, Brazilian unions were not as closely connected to government strategies so their strategies should not be equated to the government's negotiating position in regional trade agreements.
} 
comply [with the proposed Charter]. But this is a false idea because sanctions do not exist in international [labour] law as they do in domestic law. (as cited in Barbiero \& Chaloult, 2003, p. 103)

Without powers to enforce the Declaration, the emerging regional labour rights framework has nevertheless had an impact on labour politics in the Mercosur member states. Unionists indicated that they appreciated the FCES as a forum to voice civil society demands while suggesting that they could send cases of labour rights violations to the Social-Labour Commission (Barbiero \& Chaloult, 2003, p. 105; CUT, 2003, p. 99). Furthermore, Giuppone (2014, pp. 85-86) cites cases in Argentina and Brazil where national courts invoked the Social-Labour Declaration in labour conflicts, interpreting national law in relation to international labour rights instruments, including references to the right to decent work, job security, the protection of informal workers and freedom of association. Mercosur provisions have also led to joint labour inspections between Brazil, Argentina and Paraguay investigating child labour in the border regions (International Labour Office, 2009, pp. 444-445). These examples indicate that while the Mercosur provisions cannot guarantee compliance with labour rights, they have had an impact on the domestic context, not least as a reference point for labour campaigns.

Although transnational union strategies have been developed predominantly at the level of national union federations, Mercosur also facilitated cross-border collective bargaining and labour campaigns in the 1990s. The automobile sector is a rare example where regional integration, and a degree of policy co-ordination between the governments of Argentina and Brazil, was witnessed in the second half of the 1990s. The Brazilian government introduced the New Automobile Regime in 1995 within the context of the Mercosur negotiations (Gómez Mera, 2007), which included measures to promote exports, the use of national components, and state support for company restructuring (Castro, 1999, pp. 27-28). In contrast to World Trade Organization rules these policies represented a turn to state intervention to support a strategic sector of the Brazilian economy. This policy extended to the bilateral level, as the Argentinean and Brazilian governments harmonized their respective automobile sector policies within the Mercosur framework. Moreover, in March 1999 a supranational collective labour contract was agreed between Brazilian and Argentinian metalworkers' unions and Volkswagen in Brazil and Argentina, with a view of establishing Mercosur-level workers' committees for multinational enterprises operating across borders (Sindicato dos Metalúrgicos do $A B C, 1999$ ). The agreement (full text in Departamento Intersindical de Estatística e Estudos Socio-Econômicos, 2000) specified the fundamental right to unionization, information exchange between unions and management, and emphasized the importance of worker training programmes to cope with the economic crisis. Such initiatives have evolved in the automobile sector, where Brazilian unions have traditionally been strongest, but other examples of regional coordination emerged in the banking, transport, construction, textile, paper, and graphic sectors in the 1990s (Castro, 1999, pp. 14-16).

Although Mercosur created spaces for regional coordination of labour campaigns, social themes remained a secondary concern compared to trade and economic development (Dabène, 2009, p. 169; Godio, 2004, p. 23), a dynamic reinforced by the intergovernmental nature of decision-making (Doctor, 2013, pp. 529-530). Mercosur's participatory structures were organized on a tripartite basis but labour was of course not an equal partner; as union activists recognized: "despite the tripartite nature of SGT11, the decisions were made by governments" (CUT/Confédération des Sindicats Nationaux, 1996, p. 32). For the Brazilian labour movement these initiatives underlined the dual nature of the regional integration process, which reflected the insider-outsider dilemmas for civil society engagement (CUT, 2003, pp. 39-40; Orbie et al., 2016). Even if they were narrow in scope, Mercosur offered participatory structures but the dominant economic focus also reminded unionists that regional integration and trade liberalization without social safeguards could still weaken labour rights. Nevertheless, the nature of Mercosur as an agreement between developing countries, together with opportunities to discuss social dimensions meant that Brazilian trade unions decided to engage with rather than oppose regional integration, leading to several cross-border labour campaigns and initiatives intended to promote labour standards at a regional level.

\subsection{Labour Opposition to the FTAA}

If Mercosur offered trade unions several advantages to participate in debates about the social dimensions of regional integration, the proposal for a hemispheric free trade agreement became a focal point for civil society and labour opposition throughout the region. First proposed in 1994, the FTAA negotiations intensified towards the end of the 1990s in the midst of widespread opposition among Latin American social movements (Arashiro, 2011, pp. 31-35). The FTAA came to symbolize labour opposition to the growing dominance of neoliberal politics and the anticipated negative impact on jobs, wages and labour rights. Brazilian labour opposition focused not only on the negative effects of trade integration but also acquired an explicitly political dimension as the protestors merged their opposition to free trade with a rejection of neoliberal policies such as privatization, labour market flexibilization and economic liberalization. As a CUT document summarized the FTAA's wider political relevance: "the FTAA turned into a symbol of globalization and neoliberalism for the cutista labour movement" (CUT, 2003, p. 82). These ideological perspectives on globalization and free trade led to a symbolically pow- 
erful rejection of the FTAA, which left little space to negotiate labour provisions. As a result, despite provisions for civil society participation in the FTAA talks and debates on the inclusion of labour standards, civil society and labour actors comprehensively rejected the free trade agreement, without contemplating the potential benefits of the trade-labour linkage. This standpoint meant that Brazilian unions, together with many other civil society actors in Latin America, resolved the participation dilemma in favour of disengagement and opposition. In this case, the perception that an asymmetrical trade agreement between developing and developed countries would inevitably damage jobs, wages and working conditions in Latin America shaped the Brazilian labour movement's strategies vis-à-vis the FTAA. Despite Latin American union support for a binding labour clause in Mercosur, they rejected a similar proposal for hemispheric free trade. To explain the rationale for this position, labour movement strategies need to be understood in the context of the growing opposition to neoliberalism and free trade in Latin America, symbolized in the view of labour activists by the FTAA.

The initial proposals for the FTAA negotiations included labour and environmental provisions, reflecting the NAFTA experience and commitments by the Clinton administration to social and political issues (Arashiro, 2011, pp. 33-34). However, most Latin American governments rejected the inclusion of labour and environmental clauses, arguing that such provisions would lead to protectionism and should be overseen by the ILO instead. This attitude to labour provisions did not just reflect a principled position but also informed Brazilian negotiating strategies. A Brazilian trade unionist involved in FTAA summits in the late 1990s explained to me that Brazilian negotiators sometimes raised the spectre of labour standards in an attempt to stall the negotiations, reflecting their awareness of the lack of support for labour clauses within Latin America and domestic pressure in the US to address social and environmental issues (author's interview with "Paulo", December 1999). The CUT itself not only rejected the inclusion of labour clauses in the FTAA negotiations as a form of protectionism against workers in developing countries, it argued that "there is no possibility whatsoever for progressive clauses in this treaty or for it to guarantee even the bare minimum of labour rights" (as cited in American Federation of Labor and Congress of Industrial Organizations, 2001, pp. 30-31). As a result of this stalemate, the debate on labour and environmental protection was removed from the negotiations in 1998, and in the meantime trade unions were merely invited to make their views known in the negotiation process (Nelson, 2015, pp. 85-91). The unions' decision to oppose rather than engage with the FTAA process solidified their rejection of this form of free trade, despite the existence of participatory structures. In addition, although the original proposal included labour and social clauses, they did not convince Latin American unions to support the agreement.
The purpose of the union campaigns towards the FTAA was not so much to push the negotiations towards a more socially acceptable direction but to mobilize a broad civil society network against the agreement in all its aspects. With the actual negotiations about trade and a potential labour clause taking place behind closed doors (Dobrusin, 2015, p. 276), the FTAA's institutional structure also included summit meetings, which involved debates between government, business and civil society actors (Nelson, 2015, pp. 81-82). Using the summit structure to their advantage, social and labour movements began to network to establish an alternative, "people-centred" debate on hemispheric integration, which proved to be critical to the mobilization of an anti-free trade campaign. From 1997 onwards, the CUT actively participated in alternative social summits to contest the FTAA, including key roles in the Hemispheric Social Alliance against free trade and in the World Social Forum as a platform for civil society actors to contest the economic focus of global trade talks. The growing perception in Latin American countries of the wider negative impact of the agreement on public services and local communities helped broaden the anti-free trade coalition, leading to popular referendums and mass protests (Dobrusin, 2015, p. 278). This difference in strategy towards Mercosur and the FTAA indicates that while labour activists saw the former's structures and social provisions as potentially beneficial for labour rights, in the case of the latter, cross-border labour and civil society cooperation led to opposition, even if this strategy contributed to labour provisions disappearing from the agenda.

The eventual failure of the FTAA in 2005 can be attributed to a mixture of civil society opposition and the changing ideological complexion of Latin American governments around the turn of the century, underlining not only geopolitical differences between the two cases but also the changing regional political conjuncture. Until 2003 the Brazilian government's negotiating position focused on ensuring that hemispheric trade liberalization would not damage its fragile economy, arguing that the country was not yet ready for full exposure to US competition (Arashiro, 2011, pp. 123-126; Burges, 2009, p. 40). The domestic protests against the trade agreement bolstered Brazilian president Luiz Inácio Lula da Silva's own scepticism about the benefits of free trade, while growing opposition among Latin American governments meant that Brazilian representatives managed to stall the negotiations by proposing two-track negotiations, which resulted in the watering down of the agreement and its permanent suspension in 2005. In conclusion, in the case of the FTAA, labour activists rejected the entire premise of the trade agreement, including the prospect of a labour clause, because they believed that the agreement would inevitably harm workers' interests. In contrast with Mercosur, its status as an agreement between highly asymmetrical countries was therefore an important consideration for the FTAA's opponents. While labour activists campaigned for binding labour standards 
in Mercosur, they rejected this option in the case of the FTAA due to their negative perceptions of the impact a North-South trade agreement would have on Brazilian workers.

\section{Conclusion: The Prospects for Labour Standards in the Americas}

The failure of the FTAA in 2005 signalled the stagnation of multilateral trade talks involving Brazil, including those involving debates about labour standards. The cases of labour engagement with Mercosur and the FTAA underline the crucial importance of taking into account the political context in which trade negotiations take place as well as the complexity of the labour movement's perspectives and strategies in shaping the outcomes. The ambiguities evident in the Brazilian union movement's attitude towards free trade and labour provisions shows assumptions about union strategies in developing countries should be nuanced, taking into account unionists' ideas about free trade and labour as well as their interpretation of the costs and benefits of engagement with free trade negotiations. The implications of this article's findings are not limited to the cases of Mercosur and the FTAA but also inform debates and research on the impact of and prospects for improved labour standards in Latin America. The case of the FTAA underlines how the political conjuncture in which the trade talks took place shaped labour strategies towards free trade agreements, as the political climate turned increasingly hostile towards economic integration with the US at the end of the 1990s. This scepticism also explains why, despite bilateral agreements between the US and Latin American countries such as Chile, Colombia, Panama and Peru involving labour provisions (ILO, 2015, pp. 33-41), these agreements have not been expanded to other Latin American countries, such as Brazil. With the exception of sectoral agreements such as BrazilUS cooperation on biofuels, Brazil's bilateral trade negotiations have been conducted through Mercosur. Since 2000, Mercosur has negotiated a limited number of bilateral agreements with other developing countries in Latin America and the Middle East, none of which have included labour provisions. For example, Mercosur's bilateral agreements with Bolivia, Colombia, Ecuador and Peru have covered themes such as trade in goods and services, investments, intellectual property and competition policy, but not the issue of labour rights (Sanchez Badin, de Carvalho, \& Ribeiro Roriz, 2014, pp. 66, 91-92). The potential for an EU-Mercosur trade agreement to address labour issues is also low due to the EU's reluctance to move beyond a "soft" rather than a conditional approach to social and environmental standards (Adriaensen \& González Garibay, 2013) and because interregional negotiations stalled between 2004 and 2016. As negotiations resumed in 2016 Mercosur trade unions have called for civil society participation in the negotiations while simultaneously remaining sceptical about the benefits of free trade and the impact of an asymmetrical agreement on workers, echoing their position towards the FTAA (Exame, 2014; Jakobsen, 2015).

This article has analysed the variations in Brazilian union strategies towards labour standards in regional integration in the Americas, with a particular focus on Mercosur and the FTAA. The comparative discussion of the two case studies found that in the case of Mercosur, Brazilian trade unionists were willing to participate actively in debates about the regional regulation of labour standards, whereas in the case of FTAA, labour opposition contributed to the failure of the negotiations. The findings indicate that the decision to engage with free trade negotiations cannot be reduced to the existence of participatory structures or the inclusion of labour provisions in the negotiation process, which existed in both cases. The Brazilian labour movement's approach to Mercosur and the FTAA indicate a complex debate, involving the geopolitical aspects of the trade agreements, the nature of civil society participation in trade negotiations and the union movement's own ambivalence about labour and trade. To understand the reasons for these ambiguous perspectives we need to take into account the complexity of labour movement attitudes to trade-related labour standards, moving beyond the assumption that unionists in developing countries always reject them, in favour of examining the ideas that inform labour strategies. In both cases, labour activists were sceptical about the benefits of economic integration, particularly regional trade agreements without social safeguards. What makes the case of Mercosur different from the FTAA was that the labour movement's perception of the latter was overwhelmingly negative due to the asymmetric nature of the agreement. In particular, the idea that the FTAA implied a fundamentally unequal political and economic relationship between the US and Latin America sparked opposition and a refusal among Latin American labour activists to engage with its labour provisions. In the case of Mercosur, unionists were equally sceptical about free trade but nevertheless saw potential for a Latin American trading bloc to improve social conditions as long as the integration process involved strong civil society participation. These differences bring us back to the dilemma outlined at the start of this article: where trade-related labour standards were concerned, labour movements faced the dilemma whether to oppose the implementation of labour standards or use the opportunity to participate in consultations and negotiations, even if they are limited and narrow in scope. How labour activists attempted to resolve this dilemma has shaped their strategies towards trade agreements and ultimately influenced the outcomes of regional integration processes in terms of labour standards.

\section{Conflict of Interests}

The author declares no conflict of interests. 


\section{References}

American Federation of Labor and Congress of Industrial Organizations. (2001). ALCA: Os desafios de uma integração desigual [FTAA: The challenges of unequal integration]. São Paulo: AFL-CIO Solidarity Center.

Adriaensen, J., \& González Garibay, M. (2013). The illusion of choice: The European Union and the tradelabor linkage. Journal of Contemporary European Research, 9(4), 542-559.

Arashiro, Z. (2011). Negotiating the Free Trade Area of the Americas. New York, NY: Palgrave Macmillan.

Barbiero, A., \& Chaloult, Y. (2000). Desafios, estratégias e alianças das centrais sindicais no Mercosul [Challenges, strategies and alliances of central union organizations in Mercosur]. Civitas, 1(1), 55-80.

Barbiero, A., \& Chaloult, Y. (2003). Poder e déficit democrático do Mercosul: Estado, centrais sindicais e sociedade civil [Power and democratic deficit in Mercosur: State, central union organizations and civil society]. Porto Alegre: EDIPUCRS.

Bieler, A., Hilary, J., \& Lindberg, I. (2014). Trade unions, 'free trade', and the problem of transnational solidarity: An introduction. Globalizations, 11(1), 1-9.

Burges, S. W. (2009). Brazilian foreign policy after the Cold War. Gainesville, FL: University of Florida Press.

Castro, M. S. P. d. (1999). Mercosul e relaçoes trabalhistas: Informe para a OIT sobre integração económica e relações trabalhistas [Mercosur and labour relations: Report for the ILO on economic integration and labour relations]. São Paulo: Mimeo.

Castro, M. S. P. de. (2007). El sindicalismo frente al Mercosur [Trade unionism and Mercosur]. Nueva Sociedad, 211, 66-80.

Central Única dos Trabalhadores. (1994). Modelo de desenvolvimento, política industrial, e reestruturação produtiva: As propostas da CUT [Development model, industrial policy and productive restructuring: The CUT's proposals]. São Paulo: CUT.

Central Única dos Trabalhadores. (1997). Resoluções $e$ registros [Resolutions and register]. São Paulo: CUT.

Central Única dos Trabalhadores. (2003). A política internacional da CUT: História e perspectivas [The CUT's international policy: History and perspectives]. São Paulo: CUT.

Central Única dos Trabalhadores. (2015). Revisão da Declaração Sociolaboral do Mercosul [Revision of the Declaration of Social and Labour Rights of Mercosur]. CUT. Retrieved from http://cut.org.br/noticias/ revisao-da-declaracao-sociolaboral-do-mercosul-5f39

Central Única dos Trabalhadores/Conféderation des Sindicats Nacionaux. (1996). A integração das Américas: Impactos sobre o mercado de trabalho e o movimento sindical no NAFTA e no Mercosul [Integration in the Americas: Impacts on the labour market and the trade union movement in NAFTA and Mercosur]. São Paulo: CUT.

Confederação Nacional de Profissionais Liberais. (2016).
Divulgada relação das centrais sindicais certificadas para 2016 [Disclosure of certified central union organizations for 2016]. CNPL. Retrieved from http:// www.cnpl.org.br/new/index.php/sala-de-imprensa/ clipping/934-divulgada-relacao-das-centrais-sindicais -certificadas-para-2016

Dabène, O. (2009). The politics of regional integration in Latin America: Theoretical and comparative explorations. Basingstoke: Palgrave Macmillan.

Departamento Intersindical de Estatística e Estudos Socio-Econômicos. (2000). O acordo supranacional dos metalúrgicos do Brasil e da Argentina com a Volks [The supranational agreement of metalworkers in Brazil and Argentina with Volkswagen]. Boletim DIEESE, 19, 7-9.

Dobrusin, B. (2015). Transnational labor action in Latin America: From the struggle against the Free Trade Area of the Americas to the return of labor relations. Labor History, 56(3), 270-291.

Doctor, M. (2013). Prospects for deepening Mercosur integration: Economic asymmetry and institutional deficits. Review of International Political Economy, 20(3), 515-540.

Exame. (2014). Sindicatos pedem para ser ouvidos em negociações na Europa [Trade unions demand to be heard in negotiations with Europe]. Exame. Retrieved from http://exame.abril.com.br/mundo/sin dicatos-pedem-para-serem-ouvidos-em-negociacoes -na-europa

Giuppone, M. B. (2014). Free trade and labour and environmental standards in Mercosur. Colombia Internacional, 81, 67-97.

Godio, J. (2004). El Mercosur, los trabajadores y el ALCA: Un estudio sobre la relación entre el sindicalismo sociopolítico y la integración en el Cono Sur [Mercosur, workers and the FTAA: A study of the relationship between socio-political trade unionism and integration in the Southern Cone]. Buenos Aires: Editorial Biblos.

Gómez Mera, L. (2007). Macroeconomic concerns and intrastate bargains: Explaining illiberal policies in the Brazilian automobile sector. Latin American Politics \& Society, 49(1), 113-140.

González Garibay, M. G. (2009). The trade-labour linkage from the eyes of the developing countries: A euphemism for protectionist practices? European Foreign Affairs Review, 14(5), 763-784.

Griffin, G., Nyland, C., \& O’Rourke, A. (2002). Trade unions and the social clause: $A$ north-south union divide (Working Paper). Melbourne: Monash University.

International Labour Office. (2009). Application of international labour standards 2009: Report III (Part I A). Geneva: International Labour Office.

International Labour Organization. (2015). Social dimensions of free trade agreements. Geneva: International Labour Organization.

International Trade Union Confederation. (2009). Internationally recognised core labour standards in Brazil (Report for the WTO General Council review of the 
trade policies of Brazil). Geneva: International Trade Union Confederation.

Jakobsen, K. A. (2015). Política comercial brasileira e suas perspectivas pós-ALCA [Perspectives on Brazilian trade policy post-FTAA]. In G. Codas, K. Jakobsen, \& R. Spina (Eds.), ALCA dez anos: Fracasso e alerta a novas negociações [Ten years of the FTAA: Failure and alert to new negotiations] (pp. 11-20). São Paulo: Editora Fundação Perseu Abramo.

Nadvi, K. (2014). "Rising powers" and labour and environmental standards. Oxford Development Review, 42(2), 137-150.

Nelson, M. (2015). A history of the FTAA: From hegemony to fragmentation in the Americas. New York, NY: Palgrave Macmillan.

Orbie, J., Martens, D., Oehri, M., \& Van den Putte, L. (2016). Promoting sustainable development or legitimising free trade? Civil society mechanisms in EU trade agreements. Third World Thematics, 1(4), 526-546.

Pahle, S. (2014a). Bringing workers' rights back in? Propositions towards a labour-trade linkage for the Global South. Development and Change, 46(1), 121-147.

Pahle, S. (2014b). What difference does the International Labour Organization make? Freedom of association norms, supervision and promotion vis-à-vis Brazil. $L a-$ bor History, 55(4), 465-485.

Phillips, N. (2004). The Southern Cone model: The polit- ical economy of regional capitalist development in Latin America. London \& New York, NY: Routledge.

Riethof, M. (in press). Labour mobilization, politics and globalization in Brazil: Between militancy and moderation. New York, NY: Palgrave Macmillan.

Sanchez Badin, M. R., Carvalho, M. A. de, \& Ribeiro Roriz, J. H. (2014). Os acordos regionais e preferenciais de comércio do Brasil com o seu entorno [Regional and preferential trade agreements between Brazil and other countries]. In R. Baumann \& I. T. Machado Oliveira (Eds.), Os BRICS e seus vizinhos: Comércio e acordos regionais [The BRICS and their neighbours: Trade and regional agreements] (pp. 55-101). Brasília: IPEA.

Schaeffer, K. (2007). Mercosur and labor rights: The comparative strengths of sub-regional trade agreements in developing countries and enforcing labor standards in Latin American states. Columbia Journal of Transnational Law, 45, 829-867.

Silva, V. P. da. (1999, June 22). Globalização [Globalization]. CUT. Retrieved from http://www.cut.org.br/ a20107.htm

Sindicato dos Metalúrgicos do ABC. (1999). Balanço da ação sindical [Balance of trade union action]. $A B C$ de Luta. Retrieved from http://www.abcdeluta.org.br/ textos.asp?id_CON=2675

Zibechi, R. (2014). The new Brazil: Regional imperialism and the new democracy. Oakland, CA: AK Press.

\section{About the Author}

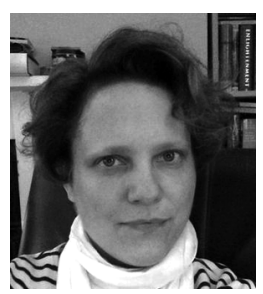

Marieke Riethof is a lecturer in Latin American politics at the University of Liverpool. Her latest publications include Labour Movements, Globalization and Militant Mobilization: The Case of Brazil (New York, NY: Palgrave, forthcoming 2018) and various articles on socio-environmental conflicts, human rights and foreign policy in Brazil. Apart from Latin American international relations, her latest research interests focus on Latin American solidarity campaigns and exile in the 1970s and 1980s, with a particular focus on Chile. 